\title{
Singles Ad: Short 6-legged Go-getter Seeks 2-legged Restoration Partner for Long-term Relationship
}

\author{
Steven N. Handel
}

T'm 'm quiet, but I'm really very social and I think we can have a very productive relationship. I thought I'd introduce myself to see if we can consider a partnership and see where it leads.

I'm outdoorsy, and like to hang out in all kinds of habitats, from fields to woods, sometimes even in deserts. I'm full of curiosity and I like long walks, stopping occasionally to explore or grab something to eat. Sometimes I find wild foods that I like to bring back home to store for later or to share with my family. Other times I feel adventurous and just want to climb trees to experience new areas that I've have never been to before. I sometimes like exploring underground areas too, searching for little secret places where I can rest and keep cool. What fun.

I'm very family-oriented, almost to a fault, I'll admit. I'm devoted to my mom. (Dad deserted us before I was born. This happens to lots of families in our community, I've learned, but we manage.) My siblings and I spend lots of time together, working around our home, cleaning up, or going out around the neighborhood. We have great times: once my sister and I found a colorful little caterpillar in the woods and brought it home to share with the youngsters; they loved it.

I do enjoy good food, all kinds of things. I crave sweet things and different grains, but I'm no vegetarian. I'll devour a good morsel of meat no matter how it's served up, even raw or dry aged. Yum. I've got big eyes, I know, but I'm no glutton; people who know me well know I'll put away left overs for a future meal, not eat it up right away. Believe me; I've got a very thin waist!

I've noticed restorationists out in the woods. I think I'd like try out a close relationship with you people. The work you do is just so interesting and I think it's really important, important to me especially as well as to so many others. So much of what I'm good at I really think would help improve your restoration ecology work. I don't have much of a formal education, but people say I have really great instincts and am full of energy, so I really get a lot done.

Ecological Restoration Vol. 32, No. 2, 2014

ISSN 1522-4740 E-ISSN 1543-4079

@ 2014 by the Board of Regents of the University of Wisconsin System.
I'm really great at improving soil. You know that's so important to modern restoration practice. I can help aerate and improve soil horizons and break down litter and other organic matter into small parcels that will build soil fertility. Eventually, this will increase survivorship of young plants and help your restoration projects be sustainable; this really aids value to the project, helps people see the progress year after year. So much of the soil you restorationists bring in is very poor quality. Not your fault; I know how hard it is to find fertile topsoil. I can chop up leaves and mix the stuff in with the mineral soil to improve soil structure. I can do this day after day and don't need any reminding! My buddies and I are really troopers. You should see us marching around the woods!

I can also help support the food webs in your new restored habitats. There's something about me that attracts lots of birdlife and even herps. I don't think a day in the field goes by when there aren't flickers around me, and so many times I see pileated woodpeckers near my home, so exciting. So the food web increases in quality and your projects are more biodiverse and sustainable. Oh, it's not just because I'm around, of course, but I know I help. Eventually, having more bird species around also increases public enjoyment and appreciation of your work. Love those cultural ecological services!

I can help you out even long after your restoration projects are initiated. I'm terrific at spreading seeds of wildflowers and other plant species around to help increase population size and landscape biodiversity. I'll carry seeds all over the place, sometimes thousands of steps away from where I first collected them! I don't charge a penny for this, unlike those pricey landscape contractors. And I'm very careful were to put seed in the ground. People who know me well say I'm as good as a lot of landscape architects at making naturalistic plantings. Because of all these different ways that I can help restoration practice, having me and my relatives around may be great indicators that a project was started right and may succeed. Where you find us, you can have confidence that the project must be going well.

We've learned that monitoring is so important in our projects. But no need to do time-consuming and expensive 
detailed monitoring of ecological health parameters; just look for us hanging out! We can't just sit plants out and walk away forever; too many landscape changes and problems can occur later that have to be dealt with. Sometimes people in the field, such as land managers, do passive monitoring, just curious to know how things change from time to time. This is so important in the world of climate change and new types of disturbances. Other time you're required to do monitoring under a legal agreement to see what trends are developing on the ground so that later interventions must be scheduled. I can help with both these things as I wander over the project site and keep workin' on my activities. These help you understand what's going on. I know some restorationists are scientists and like to do these tedious manipulative experiments to learn better restoration practice. Good for them! I can also help in testing predictions by going from treatment to treatment and helping you learn how the new plots are developing. It's no trouble for me; it's the kind of stuff I do every day.

I know most of you readers have never met me or if you've met me, you haven't paid much attention to me, 'cause I'm so petite. Please don't be put off by my small size. People have learned I have the most interesting and diverse behavioral repertoire. Look closely and you may be fascinated. I'm comfortable in so many social situations and in many venues. I don't complain about hot, sunny habitats or being in cool, moist places. You can find me active and involved almost everywhere. So consider giving me a gander to see where the relationship leads.

By the way, I know many of you have a spiritual life and that's an important source of your motivation to do restoration work. So by way of a character recommendation,
I don't mind mentioning what was written about me a while back:

Go to the ants, you sluggard; consider its ways and be wise. Book of Proverbs 6:6

Look, we live in a time when all kinds of non-traditional couples are seen together in public. You primates and we Hymenoptera, maybe can make beautiful music together. Let's get in touch. Sorry, I don't use Facebook.

\section{Recommended References}

Andersen, N. and J.D. Majer. 2004. Ants show the way Down Under: Invertebrates as bioindicators in land management. Frontiers in Ecology and the Environment 2:291-298.

Ellison, A.M., N.J. Gotelli, E.J. Farnsworth and G.D. Alpert. 2012. A field guide to the ants of New England. New Haven: Yale University Press.

Gorb, E. and S. Gorb. 2003. Seed dispersal by ants in a deciduous forest ecosystem. Dordrecht: Kluwer Academic Publishers.

Handel, S.N. and A.J. Beattie. 1990. Seed dispersal by ants. Scientific American: 263:76-83A.

Lindenmayer, D.B. and G.E. Likens. 2010. The science and application of ecological monitoring. Biological Conservation 143:1317-1328.

Lyford, W. H. 1963. Importance of ants to brown podzolic soil genesis in New England. Petersham, MA: Harvard University, Harvard Forest.

S. Sarkar, R.L. Pressey, D.P. Faith, C.R. Margules, T. Fuller, D.M. Stoms, A. Moffett, K.A. Wilson, K.J. Williams, P.H. Williams and S. Andelman. 2006. Biodiversity conservation planning tools: present status and challenges for the future. Annual Review of Environment and Resources 31:123-159.

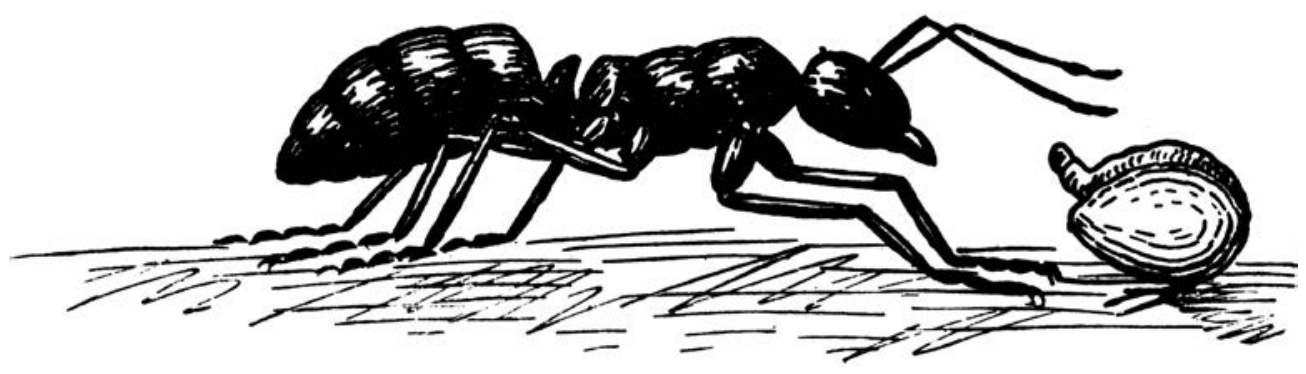

Bergen, J.Y.1896. Elements of Botany. Boston, MA: Ginn \& Company. The Florida Center for Instructional Technology, fcit.usf.edu. 